مقاله يزوهشى

مجله دانشعاه علوم يزشكى رفسنجان

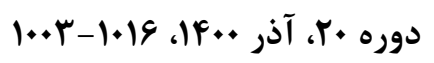

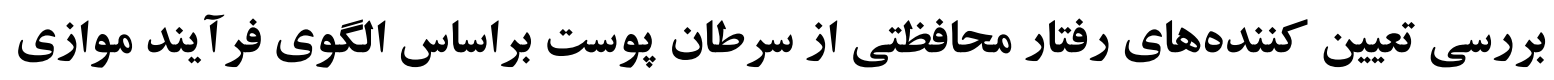

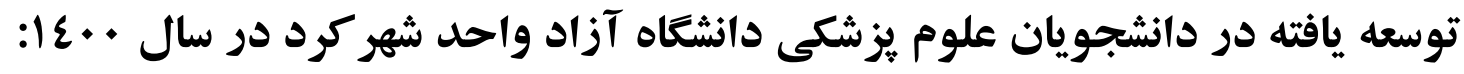
يك مطالعه توصيفى

زهره كريميان كاكلكى'، لاله رستاكى'، مريم خديبى"، بروين محمدى

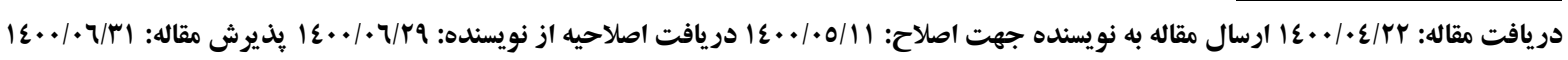
جكيده

زمينه و هدف: سرطان يوست يكى از شايعترين سرطانها است و بهترين اقدام در پيش

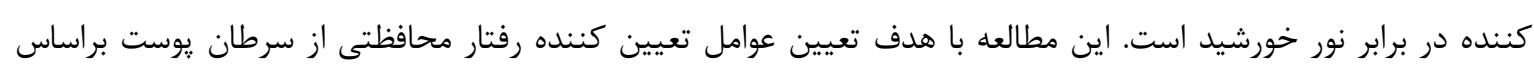

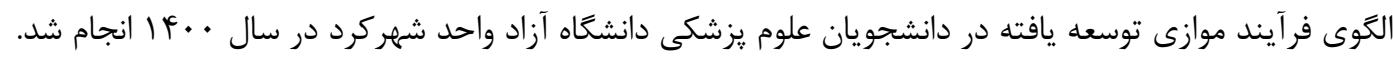

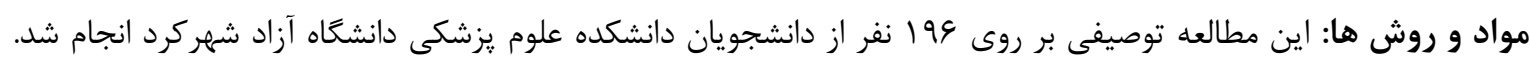

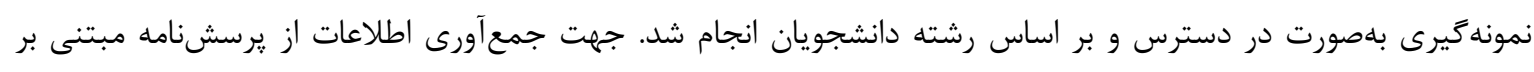

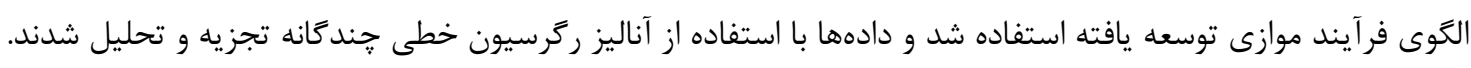

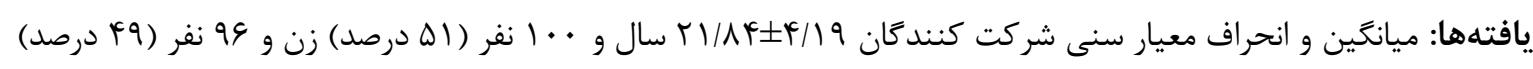

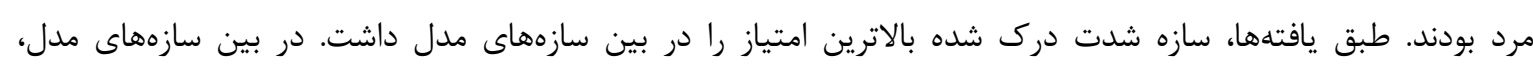

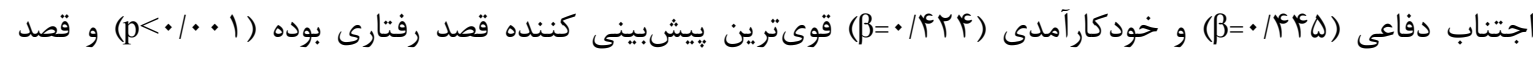

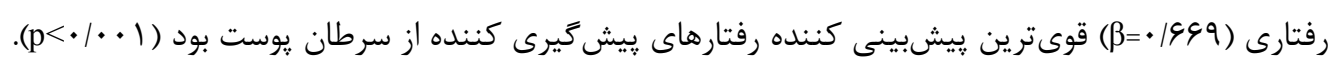

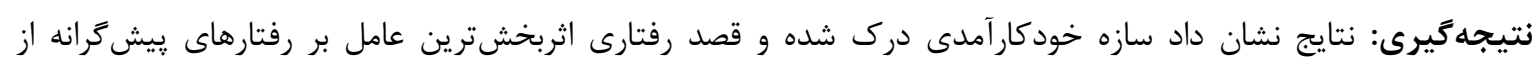

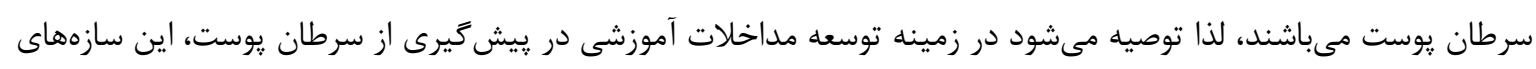
مدل بيشتر مد نظر قرار كرفته شود. وازههاى كليدى: سرطان يوست، دانشجويان، الكَوى فرآيند موازى توسعه يافته، شهر كرد

1- (نويسنده مسئول) استاديار، دكتراى آموزش بهداشت و ارتقاء سلامت، كروه بهداشت، دانشكده علوم يزشكى، واحد شهركرد، دانشكاه آزاد اسلامى، شهر كرد، ايران

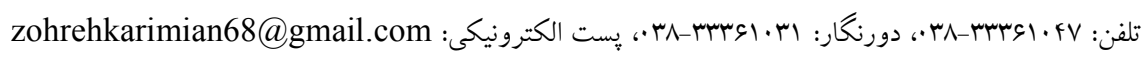

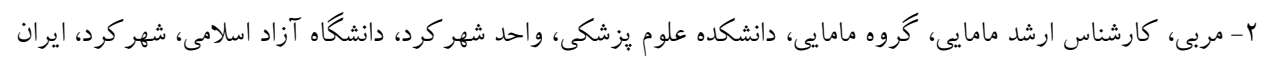

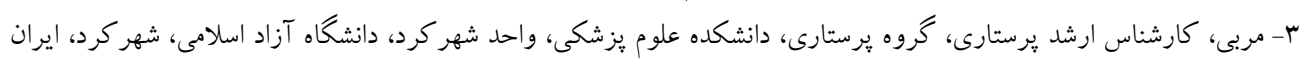

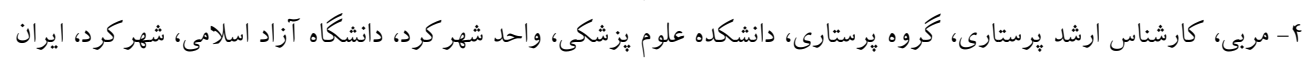


ץ . . بررسى تعيين كنندهاى رفتار محافظتى از سرطان بوست براساس الكوى فر آيند موازى ...

مههمترين عامل قابل تغيير در پيش گيرى از سرطان يوست،

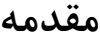

خوددارى از مواجهه با يرتو فرابنفش است [9]. تحقيقات متعددى نشان داده است كه طراحى و برنامهريزى براى ارزيابى عوامل مرتبط با يك بيمارى يا مداخلات آموزشى، مبتنى بر رويكردهاى نظريه محور هستند كه از الكَوهاى تغيير رفتار ريشه كرفتهاند. در اين راستا تئورىهاى مبتنى بر ترس يكى از راهكارهاى مؤثر در بِيشيرى از اتخاذ رفتارهاى غير بهداشتى مىباشد كه الكوى فرآيند موازى ليرى توسعه يافته (Extended Parallel Process Model; EPPM) به عنوان جهار خوب اصلى تئوريك تغيير رفتار عمل مىكند

مدل فرآيند موازى توسعه يافته تركيب فرآيندهاى عاطفى (به عنوان مثال ترس) در ارتباط با خطر را مىسنجد [1 I]]. اين مدل جامع توسط Kim Witte در سال 199 مطرح شد و فرض مى كند هنغامى كه افراد ترس يك تهديد را دارند، آنها انكَيزه اقدام براى كاهش حالت ناخوشايند را دارند. ترس مىتواند توسط اقدامات تطبيقى براى كنترل خطر و يا اقدامات ناساز ₹ار كنترل ترس كاهش يابد [11]]. در مطالعه-

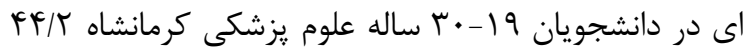
درصد دانشجويان كزارش كردند كه هميشه از ضدآفتاب استفاده مى كنند و اين مطالعه تأكيد دارد كه طراحى و دروند اجراى برنامهاى محافظتى در مقابل آفتاب براى دانشجويان

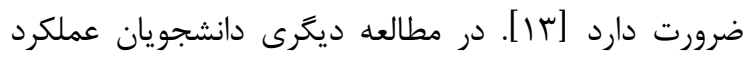
ضعيفى در خصوص انجام رفتارهاى محافظتى در مقابل

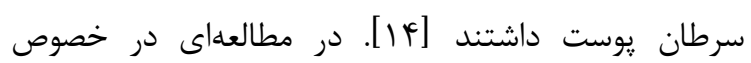
عوامل محافظتى در مقابل سرطان يوست براساس مدل فرآيند موازى توسعه يافته در دانشجويان دانشكده بهداشت

سرطان يوست يكى از شايعترين سرطانها در جهان محسوب مىشود [1]]. بر اساس آمارهاى تزارش شده توسط سازمان بهداشت جهانى، سالانه بين r تا r ميليون سرطان

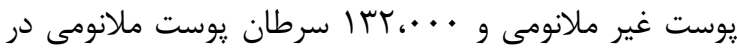
سراسر جهان رخ مى دهد [ז]. سرطان يوست شايعترين

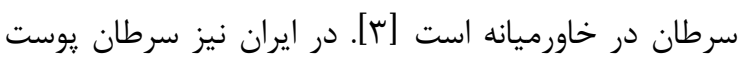
شايع بوده و در بين مردان بيشتر از زنان است و با مرك و مير بالا همراه مىباشد. مواجهه با اشعه خورشيد مىتواند از آفتاب سوختكى تا بروز سرطان همراه باشد و مىتواند

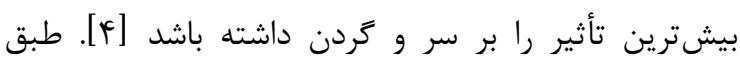
آخرين گزارش كشورى برنامه ملى ثبت سرطان كه توسط وزارت بهداشت كشور در سال ^وسا منتشر شد، ميزان بروز استاندارد شده سنى سرطان يوست (در . .... نفر) در كل جمعيت استان جهارمحال و بختيارى ه//1/ درصد، در

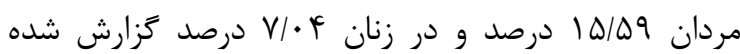
است [ه]]. در مطالعه ShahbaziGahroei و همكارش علت درد درد شيوع بالاى اين سرطان، بالابودن سطح اشعه زمينه در اين استان است [ع]. نتايج برخى مطالعات نشان داده است كه ميزان شيوع سرطان يوست در مردان، جوانان و دانشجويان بيشتر است، دانشجويان علوم يزشكى بخش وسيعى از روز و در زمان تابش بيشتر آفتاب در دانشكاه يا در كارآموزى و در معرض مواجهه با نور آفتاب قرار مى گيرند و بخش قابل توجهى از آنان به رفتارهاى محافظتى در مقابل سرطان يوست اهميت نمىدهند، لذا از اين نظر به عنوان كروه خطر

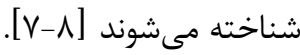




$$
n=\frac{N \times Z_{1-\frac{\alpha}{2}}^{2} \times P \times(1-P)}{(N-1) d^{2}+Z_{1-\frac{\alpha}{2}}^{2} \times P \times(1-P)}
$$

روش نمونه گيرى به صورت تصادفى طبقهبندى شده بود، به اين صورت كه در ابتدا تعداد دانشجويان در هر كدام از رشتهاى دانشكده علوم زيزشكى مشخص شده، سيس با توجه به نسبت تعداد كل دانشجويان هر رشته به تعداد كل دانشجويان جامعه هدف (دانشكده علوم يزشكى)، تعداد شركت كنندكان هر رشته نسبت به حجم نمونه (99 ( نفر) مشخص شد و نمونه قبل از جمعآورى دادهها، شركت كنندكان در زمينه اهداف طرح توجيه و با رضايت آكاهانه در مطالعه وارد شدند و به آنها اطمينان داده شد كه اطلاعات محرمانه خواهد ماند و نيازى به ذكر نام نمىباشد. در بازه زمانى فروردين و

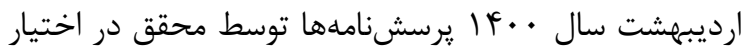
دانشجويان دانشكده علوم يزشكى قرار گرفت و به صورت خودززارشى تكميل شد. معيار ورود به مطالعه شامل دانشجوى دانشكده علوم يزشكى بودن و تمايل به شركت در مطالعه بود و معيار خروج از مطالعه عدم تمايل به همكارى و ياسخگويى به سؤالات ڤيرسشنامه بود.

جهت جمعآورى دادهها در اين يزوهش از يرسشنامه Kim Witte دمو يافته طراحى شده است و روايى و پايايى آن مورد تأييد قرار كرفته است. در مطالعه MazloomyMahmoodabad و

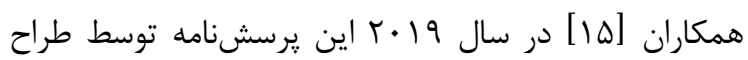
اين مدل ترجمه شده و مورد تأييد اساتيد اين حوزه قرار
يزد، دانشجويان رفتار محافظتى ضعيفى در مقابل ييش گيرى از سرطان يوست نشان دادند و از بين سازههاى مدل، خودكار آمدى ييشبينى كننده اصلى رفتار بود [ه 1]]. دانشجويان علوم يزشكى به عنوان كادر درمان و مراقبين سلامت در آينده نقش مهمى در آموزش رفتارهاى بهداشتى به جامعه دارند. به نظر مىرسد درصورتى كه خودشان نكات ييش گيرى از سرطان يوست را رعايت كنند مى توانند ارتباط لازم با جامعه را برقرار كرده و موفق به آموزش در سطح جامعه گردند. جهت بررسى بيشتر موضوع، اين مطالعه با هدف تعيين عوامل تعيين كننده رفتارهاى محافظتى از سرطان يوست با استفاده از الكوى فرآيند موازى توسعه يافته در دانشجويان علوم يزشكى دانشگاه آزاد واحد شهركرد در

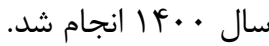

\section{مواد و روشها}

اين مطالعه به صورت توصيفى از نوع مقطعى حاصل طرح تحقيقاتى مصوب دانشعاه آزاد اسلامى واحد شهركرد با كد اخلاق IR.IAU.SHK.REC.1400.015 مىباشد. جامعه هدف كليه دانشجويان دانشكده علوم يزشكى دانشعاه آزاد واحد شهركرد شامل رشتههاى بهداشت خانواده، بهداشت مبارزه با بيمارىها، يرستارى، مامايى و ارشد مديريت خدمات بهداشتى درمانى در سال · F ا بودند. به منظور تعيين حجم نمونه با استفاده از فرمول كوكران

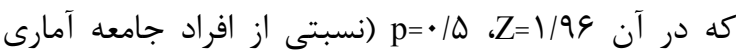

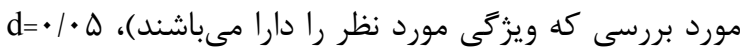
منظور شده است و با توجه به حجم جامعه محدود كه معادل N=r . . بر آورد شد. 
(مثلاً باور دارم كه سرطان يوست مشكل بسيار جدى براى سلامتى است. باور دارم كه سرطان يوست تهديد جدى براى سلامتى من است.)، سازه خودكارآمدى درك شده با 9 سؤال

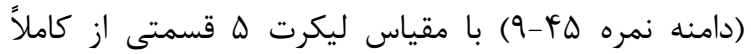

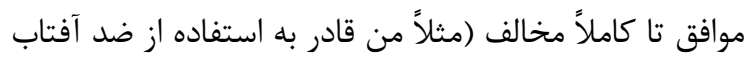
با حداقل SPF-15 يا بالاتر براى جلوكيرى از سرطان يوست

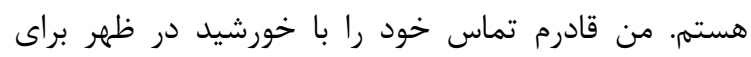
جلوكيرى از سرطان يوست به حداقل برسانم.)، سازه

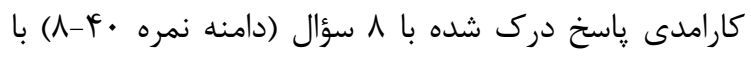

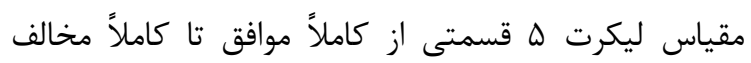

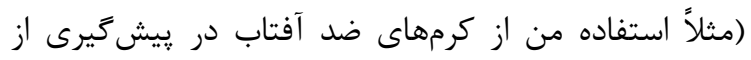

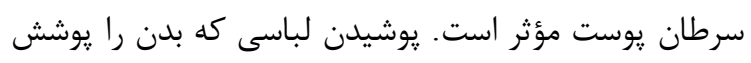
مىدهد در پِيش گيرى از سرطان يوست مؤثر است)، سازه

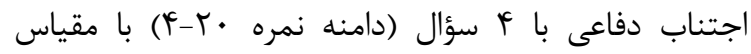

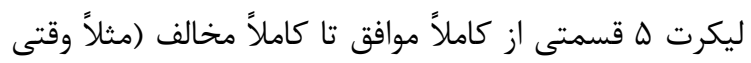
كه من در معرض افتاب هستم، تمايل دارم از افكار و انديشههاى سرطان يوست اجتناب كنه. وقتى كه من در معرض آفتاب هستم، سعى مى كنم در مورد سرطان يوست فكر نكنم.)، سازه قصدرفتارى با صا سؤال (دامنه نمره VDها) با مقياس ليكرت ه قسمتى از كاملاً موافق تا كاملاً مخالف (مثلاً من قصد استفاده از كرمهاى ضد آفتاب به طور

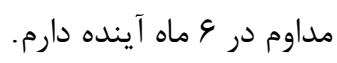
من قصد استفاده از كلاه و نقابى كه سايه براى صورتم براى جلوكيرى از سرطان يوست ايجاد نمايد دارم.) و سازه

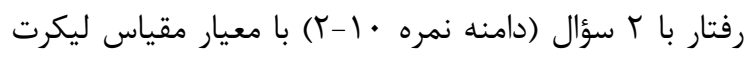

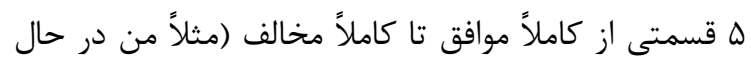
حاضر از كرمهاى ضد آفتاب هنگامى كه در مقابل نور
كرفته است. اعتبار صورى مقياس ها توسط هيأت خبر كانى مورد تأييد قرار گرفته است و ميزان سازگًارى درونى مقياس در يك مطالعه مقدماتى توسط له شركت كننده واجد شرايط انجام شده و آلفاى كرونباخ DA/ • براى هر مقياس به-

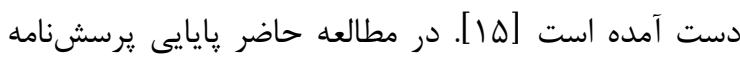
با يك مطالعه مقدماتى توسط • ب شركت كننده با آلفاى كرونباخ بالاى VD/• براى هر مقياس مورد تأييد قرار كرفت. بخش اول متغيرهاى دموكرافيك شامل: سن (سال)، جنسيت (زن و مرد)، رشته تحصيلى (بهداشت خانواده، بهداشت مبارزه با بيمارىها، برستارى، مامايى، ارشد مديريت خدمات بهداشتى درمانى)، مقطع تحصيلى (كاردانى كارشناسى، ارشد)، وضعيت اقتصادى برطبق نظر وِاسخً (ضعيف، متوسط، خوب) وضعيت تأهل (متأهل و مجرد) و رنح يوست (تيره و روشن) بود.

بخش دوم سؤالات عوامل مرتبط با تعيين كنندههاى رفتارهاى پِيشگيرى كننده مشتمل بر سازههاى ترس، حساسيت درى شده، شدت درك شده، خودكارآمدى درى شده، پاسخ كارايى، اجتناب دفاعى، قصد رفتارى و رفتار بود. سازه ترس با 9 سؤال (دامنه نمره צr-9) و طيف ليكرت 9 قسمتى از خيلى زياد تا هركز (مثلاً جقدر اين يِام در شما

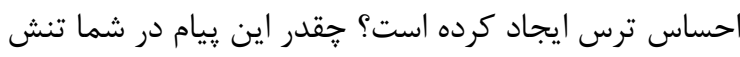
ايجاد كرد؟)، سازه حساسيت درك شده با ب سؤال (دامنه

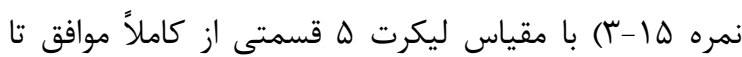
كاملاً مخالف (مثلاً من در خطر ابتلاء به سرطان يوست هستم. ممكن است كه من سرطان يوست گرفتار شوم)،

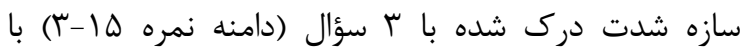
مقياس ليكرت ه قسمتى از كاملاً موافق تا كاملاً مخالف 


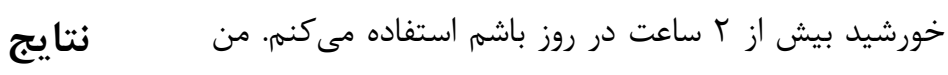
در اين يزوهش 199 نفر از دانشجويان دانشكده علوم يزشكى دانشعاه آزاد شهركرد از تمام رشتههاى اين دانشكده شامل بهداشت خانواده، بهداشت مبارزه با بيمارىها، يرستارى، مامايى و ارشد مديريت خدمات بهداشتى درمانى شركت كردند. ميانكين و انحراف معيار سنى شركت كنند

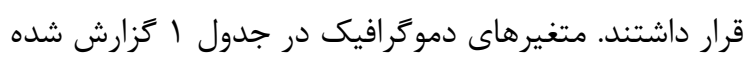
در حال حاضر براى محافظت از سرطان يوست در مواجهه بيش از حد خورشيد كلاه مىيوشم.) سنجيده مىشود. اطلاعات جمعآورى شده يس از كدگذارى با استفاده از نرمافزار SPSS نسخه 1 ل مورد آناليز قرار كرفت و شاخصهاى توصيفى شامل ميانگين نمره و انحراف معيار كزارش شده است و از رگرسيون خطى جندگَانه جهت آناليز دادهها استفاده شد. سطح معنى دارى در آزمونها هـ • • در است.

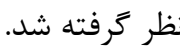

\section{جدول | - خصوصيات دموكرافيك دانشجويان علوم يزشكى آزاد شهركرد در سال ..ـ1}

\begin{tabular}{|c|c|c|c|}
\hline درصد & تعداد & & 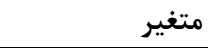 \\
\hline$\Delta 1$ & $1 \cdots$ & 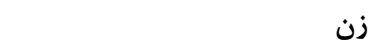 & جنسيت \\
\hline$p q$ & 99 & 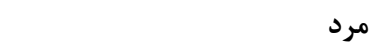 & \\
\hline$\Lambda \mu / \mu$ & 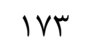 & مجرد & وضعيت تأهل \\
\hline $11 / \mathrm{V}$ & r & متأهل & \\
\hline $94 / 9$ & 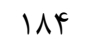 & 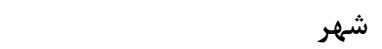 & محل سكونت \\
\hline $4 / 1$ & it & 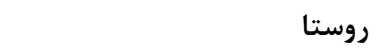 & \\
\hline$V / 1$ & If & ضعيف & وضعيت اقتصادى \\
\hline$V 1 / 9$ & $|f|$ & 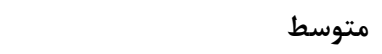 & \\
\hline$r \cdot / 9$ & (i) & 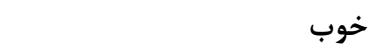 & \\
\hline $4 i / r$ & $\wedge 1$ & تيره & رنت يوست \\
\hline$\Delta \wedge / \vee$ & 110 & ر & \\
\hline $19 / 9$ & rq & بهداشت خانواده & رشته تحصيلى \\
\hline $18 / \pi$ & rt & بهداشت مبارزه با بيمارىها & \\
\hline Tr/T & 90 & يرستارى & \\
\hline$r \Delta / \cdot$ & $p q$ & مامايى & \\
\hline$\Delta / 9$ & 11 & ارشد مديريت خدمات بهداشتى & \\
\hline 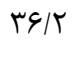 & vi & كاردانى & مقطع تحصيلى \\
\hline$\Delta \Lambda / T$ & 114 & كارشناسى & \\
\hline$\Delta / 9$ & 11 & ارشد & \\
\hline
\end{tabular}


1 • • ا بررسى تعيين كنندهاى رفتار محافظتى از سرطان بوست براساس الكوى فر آيند موازى ...

درصد از ماكزيمم نمره قابل كسب، يايينترين امتياز را در

طبق جدول r، سازه شدت درك شده با كسب

ميان سازمهاى مورد مطالعه نشان داد.

درصد از ماكزيمم نمره قابل كسب بالاترين امتياز را به خود

اختصاص داده است و سازه اجتناب دفاعى نيز با كسب qq/9

جلدول r - توزيع فراوانى سازههاى ملدل در دانشجويان علوم بزشكى آزاد شهركود در سال ..

\begin{tabular}{ccccc}
\hline متغير & مترس
\end{tabular}

حساسيت درك شده

شدت درك شده

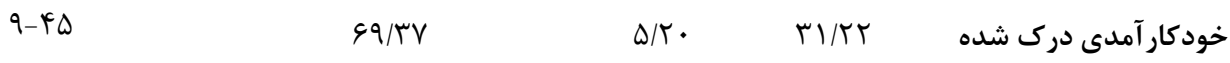

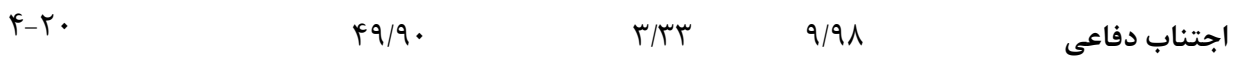

Sار امدى ياسخ درك شده

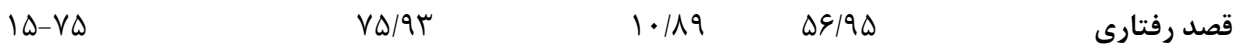

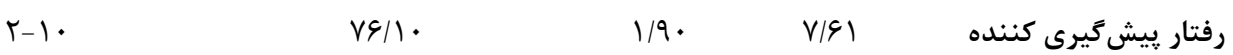

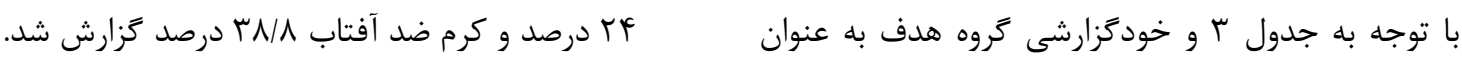
رفتار يِيش گيرى كننده از سرطان، موافقين استفاده از كلاه

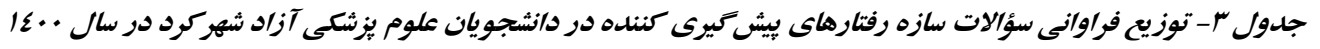

\begin{tabular}{|c|c|c|c|c|c|c|c|c|c|c|c|}
\hline \multirow[b]{2}{*}{ ميانغين آيتم } & \multicolumn{2}{|c|}{ كاملاً مخالفه } & \multicolumn{2}{|c|}{ مخالفم } & \multicolumn{2}{|c|}{ نظرى ندارم } & \multicolumn{2}{|c|}{ موافقم } & \multicolumn{2}{|c|}{ كاملاً موافقم } & \multirow[b]{2}{*}{ سؤالات رفتارى } \\
\hline & درصد & تعداد & درصد & تعداد & درصد & تعداد & درصد & تعداد & درصد & تعداد & \\
\hline$f / \cdot 1$ & $f / 1$ & $\wedge$ & $9 / 4$ & 11 & $V / I$ & If & $r \cdot / \Lambda$ & $\wedge \cdot$ & rN/A & VE & 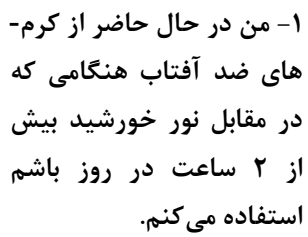 \\
\hline$r / 4$. & $\Delta / 1$ & 1. & $I V / r$ & mF & $1 \pi / \Lambda$ & tr & $r q / \wedge$ & $\vee \wedge$ & TF & FV & 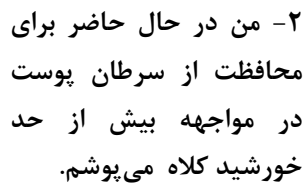 \\
\hline
\end{tabular}

رفتارى با استفاده از بررسى نمودار هيستوكرام و وجود شكل

توزيع نرمال انجام گرفت. يِيش فرض استقلال خطاها با

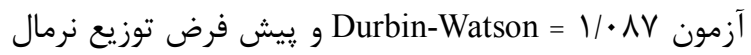

جدول عا، نتايج آناليز رگرسيون خطى به روش Enter براى پيشبينى كنندههاى قصد رفتارى در دانشجويان را نشان مىدهد. بررسى ييش فرض نرمال بودن متغير قصد 
متغيرهاى ترس، حساسيت درك شده، شدت درك شده، خودكارآمدى درك شده مىباشد. ضرايب بتا استاندارد نشده دو متغير خودكارآمدى درك شده و قصد رفتارى نشان مىدهد با افزايش يك نمره در خودكارآمدى درك شده و اجتناب دفاعى، ميانگين نمره قصد رفتارى دانشجويان به

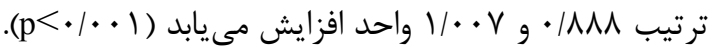

خطاها با استفاده از Normal P-P Plot و يراكندگى نقاط حول خط ها درجه تأييد گرديد. نتايج مربوط به بررسى Collinearity Condition Index $=V / T 9 \Delta-r \vee / r \wedge \varphi$, Eigenvalue مورد تأييد قرار كرفت. مقدار ضريب تعيين (R²) مدل ركرسيون نشان مىدهد ع هر در از كل نمره قصد رفتارى دانشجويان وابسته به

جلدول ع- آناليز ركرسيون سازهاى ملدل به عنوان بيشبينى كنندههاى قصد رفنارى در دانشجويان علوم يزشكى آزاد شهركرد در سال ..عا

\begin{tabular}{|c|c|c|c|c|c|c|}
\hline $\mathbf{R}^{2}$ & مقدار p p & مقدار t & خطاى معيار بتا & بتا استاندارد & بتا استاندارد & متغير هاى مستقل \\
\hline \multirow{6}{*}{$\cdot 109}$. &.$/ \cdot 14$ & $r / \Delta T \mid$ & .1 .94 & . & $\cdot / 1 \Delta \varphi$ & 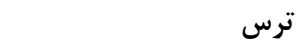 \\
\hline & $\cdot / \uparrow \wedge \Delta$ & $\cdot / V \cdot \cdot$ & $.11 \vee 9$ & (1. &.$/ 1 T s$ & حساسيت درك شده \\
\hline & $\cdot / \wedge \Delta \Delta \cdot$ & $-\cdot / 1 \Lambda r$ &.$/ K \& V$ &.$- / \cdot 1 \cdot$ & $-.1 .4 q$ & شدت درك شده \\
\hline & $<\cdot \mid \cdot \cdot 1$ & V/VIT & .1110 & . IFTF & $\cdot \mid \mathrm{AM \Lambda}$ & خودكار آمدى درك شده \\
\hline & $\cdot / \cdot Y Y$ & $r / T V \Lambda$ & $\cdot / 109$ &.$/ 111$ & . TES & كار آمدى پاسخ درك شده \\
\hline & $<\cdot / \cdot \cdot 1$ & $V / 9 \cdot V$ &.$/ 1 T V$ & $\cdot / F F \Delta$ & $1 / \cdots V$ & اجتناب دفاعى \\
\hline
\end{tabular}

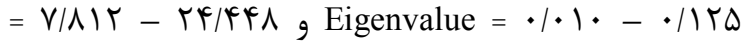
Condition Index ضريب تعيين نشان داد كه QT/9 درصد از كل نمره رفتار دانشجويان وابسته به متغيرهاى ترس، حساسيت درك شده، خودكارآمدى درى شده، ياسخ كارايى، اجتناب دفاعى و قصد رفتارى مى باشد. در اين مدل، با افزايش يك نمره در متغير قصد رفتارى، ميانگين نمره رفتار رِيش ريرانه از سرطان در دانشجويان، به اندازه IV IV • افزايش مىيابد .$(\mathrm{p}<\cdot 1 \cdot \cdot 1)$
نتايج آناليز رگرسيون خطى براى ييشبينى كنندههاى رفتار پيش گيرانه از سرطان يوست در دانشجويان در جدول ه نشان داده شده است. بررسى يِيش فرض نرمال بودن متغير ر رفتار يشگيرانه با استفاده از بررسى نمودار هيستوكرام و وجود شكل توزيع نرمال انجام گرفت. پيش فرض استقلال خطاها با آزمون Vurbin-Watson = Normal P-P ييش فرض توزيع نرمال خطاها با استفاده از Plot نتايج مربوط به بررسى Collinearity با استفاده از شاخص 
• 1 • بررسى تعيين كنندهاى رفتار محافظتى از سرطان يوست براساس الخوى فرآيند موازى ...

جدول ه- آناليز ركوسيون سازههاى مدل به عنوان بيشبينى كنندهاى رفنار در دانشجويان علوم يزشكى آزاد شهركود در سال ..ع|

\begin{tabular}{|c|c|c|c|c|c|c|}
\hline $\mathbf{R}^{2}$ & مقدار p p & t & خطاى معيار بتا & بتا استاندارد & بتا استاندارد & متغير هاى مستقل \\
\hline \multirow{7}{*}{$\cdot 1 \Delta T^{\prime}$} & $\cdot / F \Delta F$ & $-\cdot / V \Delta \cdot$ & $.1 \cdot 11$ & $-\cdot / \cdot r \Lambda$ & $-\cdot / \cdot \cdot 1$ & 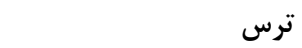 \\
\hline & $\cdot / \Delta T \Delta$ & $-\cdot \mid \& \mathrm{~F} \Lambda$ & t. & $-\cdot / \cdot r f$ & $-\cdot|\cdot r|$ & حساسيت درك شده \\
\hline & $\cdot / \cdot r$. & $-T / / \Lambda \varphi$ & $\cdot 1 \cdot 4 \wedge$ & $-\cdot / 1 T V$ & $-\cdot / 1 \cdot \Delta$ & شدت درى شده \\
\hline &.$/ 1 V \mu$ & $1 / T \& V$ & $\cdot 1 \cdot \mathrm{TF}$ & $\cdot 1 \cdot 19$ & ( & خودكار آمدى درك شده \\
\hline & $\cdot 1 \cdot 19$ & $r / T \& V$ & $\cdot 1 \cdot r q$ & $.|| r \mid$ & .1 .99 & كار آمدى پاسخ درى شده \\
\hline & $\cdot \mid r \& \Lambda$ & $1 / 111$ & $\cdot / \cdot T V$ & $\cdot 1 \cdot v \Delta$ & $\cdot 1 \cdot r q$ & اجتناب دفاعى \\
\hline & $<\cdot 1 \cdot \cdot 1$ & $\wedge / \wedge 9 \Delta$ & $\cdot 1 \cdot 14$ & $\cdot 1999$ & $.111 \mathrm{~V}$ & قصد رفتارى \\
\hline
\end{tabular}

علت يذيرش بالاتر اين رفتار در اين قشر از جامعه مىباشد، حال آن كه يذيرش و انجام اين رفتار در برخى از اقشار جامعه مثل كشاورزان يا ملوانان پايين است. نكته با اهميت ديكر در خصوص اين رفتار تمديد استفاده از اين روش مىباشد. گرجه در مطالعهاى نتايج نشان داد كه دانش آموزان در تمديد استفاده هر קند ساعت از كرم ضد آفتاب

ضعف دارند [TY] استفاده از كلاه يا كلاه نقابدار به عنوان يك روش

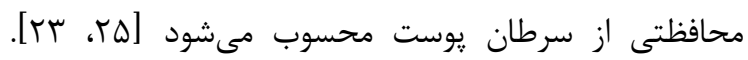
رفتار استفاده از كلاه بهعنوان يك وسيله حفاظتى و رفتار خودمراقبتى در مطالعه ما با مطالعهاى در دانشجويان علوم يزشكى يزد همسو مىباشد كه اين ميزان קايين كزارش شد

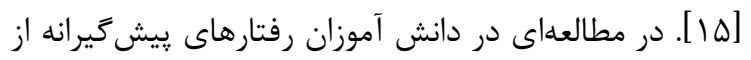
سرطان يوست از قبيل استفاده از كلاه نقابدار ضعيف بود

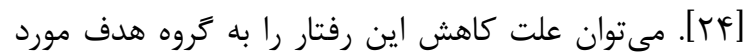
مطالعه و مسائل فرهنگى مرتبط دانست، يذيرش پايين اين روش در جامعه مىتواند در كاهش استفاده از آن نقش لنش داشته باشد. اين مطالعه با هدف تعيين عوامل تعيين كننده رفتار محافظتى در مقابل سرطان يوست براساس الكَوى فرآيند موازى توسعه يافته در دانشجويان علوم يزشكى دانشكاه آزاد واحد شهركرد صورت گرفت. نتايج نشان داد رفتارهاى ييش گيرانه كَروه هدف با توجه به درصد ميانكَين از ماكزيمه مطلوب نمىباشد كه اين نتايج با مطالعات متعددى همسو بود [9 1911]، كه نشان دادند رفتارهاى ييش برانه در مقابل سرطان يوست پايين است. با توجه به نتايج درصد رفتار استفاده از كرم ضد آفتاب در دانشجويان بيشتر بود كه همسو با نتايج برخى مطالعات مىباشد [إr-r.r ها] كرم ضد آفتاب /N/A درصد بود ولى در مطالعات ديخر [بr،

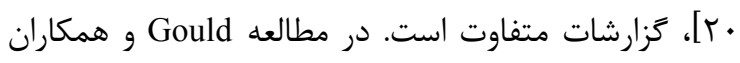
انجام رفتارهاى محافظتى در مقابل نور خورشيد ضعيف بود

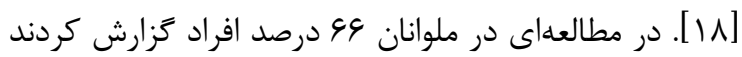

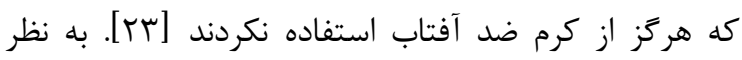
مىرسد استفاده بيشتر دانشجويان از كرم ضد آفتاب به 
آץ]، اين مطالعات نشان دادند وقتى افراد توانايى كنترل جالشهاى زندكى خود را داشته باشند، اين احساس باعث افزايش استقلال و مسئوليت يذيرى آنها در كنترل سلامت خود و انجام رفتار بيش يشيرى از بيمارى مىشود. رابطه بين قصد رفتارى و انجام رفتارهاى پِيش گيرى كننده، بيانكر اين است هر جه قصد فرد براى انجام رفتار بيشتر باشد، احتمال انجام آن رفتار نيز در آينده بيشتر خواهد شد كه با مطالعه Mohammadi و همكاران همسو است [إr]. محقق با دانستن عوامل اصلى مؤثر بر رفتارهاى ״يش گيرى كننده از سرطان يوست، موفق به بهبود رفتار در كروه هدف خواهد شد. مثلاً در مطالعهاى سازه هنجار ذهنى و در مطالعه ديكرى سازه خودكارآمدى [ها] و در مطالعه حاضر سازه قصد بِيش بينى كنندهاى اصلى رفتار هستند. ارزيابى ذهنى رفتار از جمله محدوديتهاى اين مطالعه است كه يِينهاد مىشود در مطالعات آتى ارزيابى عينى با קك ليست صورت يذيرد. از آنجا كه اطلاعات بهصورت خودَزارشى جمعآورى شده، تورش در جمعآورى دادهها ممكن است وجود داشته باشد كه سعى شد با اطمينان به كروه هدف و همرجنين جلب اعتماد، اطلاعات جمعآورى شود. در مطالعات آتى ييشنهاد مىشود يرسش تكميل يرسشنامهها حضور داشته باشد. با توجه به كاربرد سازههاى اين مدل در طراحى مداخلات، يُشنهاد مىشود در مطالعات آتى از نتايج مطالعه حاضر در برنامههاى مداخلهاى

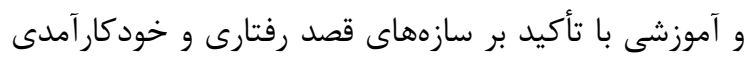
استفاده شود. همجنين با توجه به سطح بالاى تابش آفتاب در استان جهارمحال و بختيارى كه در مطالعات به آن اشاره
نتايج نشان داد سازه شدت درك شده بالاترين درصد ميانكين نمره از ماكزيمم را بين سازهها دارد كه بيانكر جدى بودن اين بيمارى از ديدگاه دانشجويان است ولى به نسبت ميانگين نمره اجتناب دفاعى خوبى نداشتند كه مىتواند از اين منظر باشد خود را در معرض خطر بيمارى نمى ببيند كه مشابه مطالعه Allahverdipour و همكاران در زمينه مواد

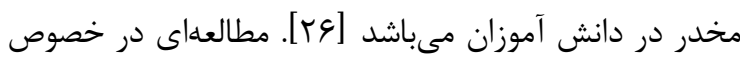
رفتارهاى پيشگيرانه تأكيد داشت كه شدت درى شده تهديد و يِيامدهاى آن از عوامل اصلى انجام تستهاى غربالكرى و پِيش دانشجويان نسبت به اهميت و جديت بيمارى سرطان يوست نكَرش خوبى دارند و اين مىتواند نقطه اتكايى جهت انجام مداخلات رفتارهاى يیش يرانه در زمينه سرطان يوست در

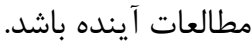
در مطالعه كنونى سازه خودكارآمدى درك شده و اجتناب دفاعى قوىترين پيشبينى كننده قصد رفتارى بودند و قصد رفتارى قوىترين يِيشبينى كننده رفتار پِيش گيرانه بود. اين رابطه خطى بين سازهها نشان دهنده اين نكته است كه دركير شدن فرد در فرآيندهاى عاطفى مثل تمايل به فرار از موضوع و توانمندى افراد، آنها را آماده و مصمم جهت قصد انجام رفتار نموده و در نهايت قصد افراد به عمل مىانجامد، بنابرين مىتوان به نحوى خودكارآمدى را در بروز رفتار ريشگيرانه مؤثر دانست. همسو با اين نتايج مطالعات متعددى اهميت خودكارآمدى درى شده را در ارتقاء رفتارهاى پيش

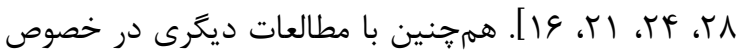
تأثير خودكارآمدى بر رفتار پِيش 
ז ا • ا بررسى تعيين كنندهاى رفتار محافظتى از سرطان يوست براساس الخوى فر آيند موازى ...

در آنها بيشتر است. با توجه به اينكه در اين مطالعه اهميت وسايل حفاظتى زيشيرى كننده از سرطان يوست مثلاً كلاه نقابدار كمتر مورد توجه دانشجويان قرار كرفتهاند، ييشنهاد مىشود كه مطالعات تكميلى و جامعهنكر بر مبناى اين مدل به صورت آموزشى انجام شود تا يذيرش اين رفتار افزايش يافته و رفتارهاى محافظتى آنان ارتقاء يابد.

$$
\text { تشكر و قدردانى }
$$

اين مطالعه حاصل طرح تحقيقاتى مصوب دانشگاه آزاد اسلامى واحد شهركرد مىباشد. بدينوسيله از معاونت محترم يزوهشى دانشگاه به عنوان حامى مالى طرح، رياست محترم دانشكده علوم يزشكى اين دانشكاه و كليه دانشجويان دانشكده علوم يزشكى كه ما را در انجام اين يزوهش همراهى كردند قدردانى مىشود.
شد، مىتوان در مداخلات آتى وسايل محافظتى از قبيل كرم ضد آفتاب و كلاه نقابدار را به شركت كنند نتيبجه گيرى طبق نتايج مطالعه حاضر بهطور خلاصه خودكارآمدى درك شده و اجتناب دفاعى عوامل مههم در يِشبينى قصد رفتارى بوده و قصد رفتارى ييشبينى كننده اصلى رفتارهاى خودمراقبتى از سرطان يوست مىباشد. بنابراين، براى تهيه يك برنامه اصلاح رفتارى مبتنى بر مدل الكوى فرآيند موازى توسعه يافته در دانشجويان، توصيه مىشود بيشتر بر روى اين سازهها تأكيد شود. از طرفى نتيجه مطالعه حاضر مى تواند يك كام مثبت جهت ارتقاء سلامت دانشجويان علوم يزشكى در اين زمينه باشد، اين دانشجويان مراقبين سلامت در آينده خواهند بود و اهميت اجراى رفتارهاى پيش

\section{References}

[1] Lomas A, Leonardi-Bee J, Bath-Hextall F. A systematic review of worldwide incidence of nonmelanoma skin cancer. $B r J$ Dermatol 2012; 166(5): 1069-80.

[2] WHO (2015) Skin Cancers. How common is skin cancer? Available at: www.WHO. int/uv/faq/ skincancer/en. Accessed 12 Oct 2015.
[3] Afzali M, Mirzaei M, Saadati H, Mazlomy SS. Epidemiology of skin cancer and changes in its trends in Iran. Feyz 2013; 17(5): 501-11. [Farsi]

[4] Raeisi R, Bayati A, Karami J, Sarkargar AA, Katorani S, Ramazan Nejad P, et al. Spatial distribution of multiple sclerosis disease in Chaharmahal va 
Bakhtiari province in 20-year period. J Shahrekord Univ Med Sci 2013; 15(4): 73-82. [Farsi]

[5] National report; Registers Cancer cases, 2016, Diseases Management Center, Non Infectious Section, Cancer Office, 2019.

[6] ShahbaziGahroei D, Danesh A. Investigating the prevalence of radiation-related cancers in Chaharmahal and Bakhtiari province for 5 years. $J$ Shahrekord Univ Med Sci 2000; 6(1): 7-13. [Farsi]

[7] Alberg AJ, Herbst RM, Genkinger JM, Duszynski KR. Knowledge, attitudes, and behaviors toward skin cancer in Maryland youths. J Adolesc Health 2002; 31(4): 372-7.

[8] Galán I, Rodríguez-Laso A, Díez-Gañán L, Cámara E. Prevalence and correlates of skin cancer risk behaviors in Madrid (Spain). Gac Sanit 2011; 25(1): 44-9.

[9] Zareban I, Izadirad H, Masoudy G, The effect of educational intervention on preventive practices of skin cancer among female high school students based on BASNEF model. J Health 2016; 7(3): 302-11.
[10] Glanz K, Rimer BK, Viswanath K. Health Behavior and Health Education: Theory, Research, and practice, Jossey-Bass; 2008.

[11] Witte K. Putting the fear back into fear appeals: The extended parallel process model. Commun Monogr 1992; 59(4): 329-49.

[12] Birmingham W.C, Hung M, Boonyasiriwat W, Kohlmann W, Walters ST, Burt RW, et al. Effectiveness of the extended parallel process model in promoting colorectal cancer screening. Psychooncology 2015; 24(10): 1265-78.

[13] Mirzaei-Alavijeh M, Gharibnavaz H, Jalilian F. Skin Cancer Prevention: Psychosocial Predictors of Sunscreen Use in University Students. J Cancer Educ 2020; 35(1): 187-92.

[14] Dehbari S.R, Dehdari T, Dehdari L, Mahmoudi M. Predictors of sun-protective practices among Iranian female college students: application of protection motivation theory. Asian Pac J Cancer Prev 2015; 16(15): 6477-80.

[15] MazloomyMahmoodabad S.S, Gerayllo S, Mizani N. Factors Influencing Skin Cancer Preventive Behaviors Based on the Extended Parallel Process 
Model in Yazd University of Medical Sciences Students, 2017. J Community Health Res 2019; 8(3): 148-55.

[16] Babazadeh T, Nadrian H, Banayejeddi M, Rezapour B. Determinants of skin cancer preventive behaviors among rural farmers in Iran: an application of protection motivation theory. J Cancer Educ 2017; 32(3): 604-12.

[17] Carley A, Stratman E. Skin cancer beliefs, knowledge, and prevention practices: a comparison of farmers and nonfarmers in a midwestern population. $J$ Agromedicine 2015; 20(2): 85-94.

[18] Gould M, Farrar M, Kift R, Berry J, Mughal M, Bundy C, et al. Sunlight exposure and photoprotection behaviour of white Caucasian adolescents in the UK. J Eur Acad Dermatol Venereol 2015; 29(4): 732-7.

[19] Mazarei M, Abedini S, Mohseni S, M Salehi M. Knowledge, Attitudes and Behaviors of Students of Hormozgan University of Medical Sciences about Skin Cancer. Int. Electron J Med 2020; 8(1): 17-23.
[20] Davati A, Pirasteh A, Yahyaei M, Shakouri A. Skin protective behavior amongst girl students; based on health belief model. Acta Med Iran 2013; 51(9): 626.

[21] Mohammadi S, Baghiani Moghadam MH, Noorbala MT, Mazloomi SS, Fallahzadeh H, Daya A. Survey about the role of appearance concern with skin cancer prevention behavior based on protection motivation theory. J. Cosmet. Dermatol 2010; 1(2): 70-7. [Farsi]

[22] Benvenuto-Andrade C, Zen B, Fonseca G, Villa D, Cestari T. Sun Exposure and Sun Protection Habits Among High-school Adolescents in Porto Alegre, Brazil. J Photochem Photobiol 2005; 81(3): 630-65.

[23] Sotoudeh A, Mazloomy Mahmoodabad SS, Fattahi M. Knowledge and Practice of Skin Cancer Prevention in Sailors in Southern Iran in 2019. J. Mar Med 2021; 2(4): 237-43. [Farsi]

[24] Najafi A, Nadrian E, Bakri G, Nadrian H, Fathipour A. Skin Cancer Preventive Behaviors and its Determinants among High School Students in Sanandaj, Iran: An Application of PRECEDE Model. J Educ Community Health 2017; 4(1): 1-10. [Farsi]

[25] Hazavehei MM, Salimi N, Gheysvandi E, Dogonchi M, Ezzati Rastgar K. The effect of educational 
interventions in increasing skin cancer preventive behaviors in people over 18 years: a systematic review. Med Sci J Islamic Azad Univ Tehran Med Branch 2018; 28(3): 171-80. [Farsi]

[26] Allahverdipour H, Hidarnia A, Kazemnejad A, Shafii F, Azad Fallah P, Mirzaee E, et al. Assessment of substance abuse behaviors in adolescents': integration of self-control into extended parallel process model. $J$ Shaheed Sadoughi Univ Med Sci 2005; 13(1): 21-31. [Farsi]

[27] Shi J, Smith SW. The effects of fear appeal message repetition on perceived threat, perceived efficacy, and behavioral intention in the extended parallel process model. Health Commun 2016; 31(3): 275-86.

[28] Heckman CJ, Manne SL, Kloss JD, Bass SB, Collins B, Lessin SR. Beliefs and intentions for skin protection and UV exposure in young adults. $\mathrm{Am} \mathrm{J}$ Health Behav 2011; 35(6): 699-711.

[29] Jasemzadeh M, Jaafarzadeh N, Khafaie MA, Malehi AS, Araban M. Predicator of pregnant women's selfcare behavior against air pollution: an explanation based on the extended parallel process model (EPPM). Electron Physician 2016; 8(9): 2871. [Farsi]

[30] Nadrian H, Rahaee Z, Mazloomy Mahmoodabad SS, Bahrevar V, Khajeh Z, Najafi S, et al. Effects of educational intervention on promoting skin cancer preventive behaviors and its predisposing factors among female students in Yazd city: An application of some PRECEDE Model constructs. RJMS 2014; 21(126): 55-64. [Farsi]

[31] Luszczynska A, Durawa AB, Scholz U, Knoll N. Empowerment beliefs and intention to uptake cervical cancer screening: three psychosocial mediating mechanisms. Women Health 2012; 52(2): 162-81.

[32] Maunsell E, Lauzier S, Brunet J, Pelletier S, Osborne RH, Campbell HS. Health-related empowerment in cancer: Validity of scales from the Health Education Impact Questionnaire. Cancer 2014; 120(20): 322836. 
19 • إبررسى تعيين كنندههاى رفتار محافظتى از سرطان بوست براساس الخوى فر آيند موازى ...

\title{
Study of the Determinants of Protective Behavior against Skin Cancer Based on the Extended Parallel Process Model in Medical Students of Shahrekord Branch of Azad University in 2021: A Descriptive Study
}

\author{
$\underline{\text { Z. Karimiankakolaki', L. Rastak }}{ }^{\Upsilon}$, M. Khadibi ${ }^{r}$, P. Mohammadi ${ }^{\uparrow}$
}

Received: 13/07/21 Sent for Revision: 02/08/21 Received Revised Manuscript: 20/09/21 Accepted:22/09/21

Background and Objectives: Skin cancer is one of the most common cancers, and the best way to prevent it is to protect yourself from the sun. The aim of this study was to determine the factors determining the protective behavior of skin cancer based on the extended parallel process model in medical students of Shahrekord Branch of Azad University in 2021. Materials and Methods: This descriptive study was conducted on 196 students of Shahrekord Azad University School of Medical Sciences. Convenience (available) sampling was applied according to students' field. A questionnaire based on the extended parallel processes model was used to collect information, and data was analyzed using analysis of multiple linear regression.

Results: The mean and standard deviation of age of participants were $21.84 \pm 4.19$ years and 100 (51\%) were female and 96 (49\%) were male. According to the findings, the perceived intensity structure had the highest score among the model structures. Among the constructs of defensive avoidance model $(\beta=0.445)$ and self-efficacy $(\beta=0.424)$, the strongest predictor was behavioral intention $(\mathrm{p}<0.001)$, and behavioral intention $(\beta=0.669)$ was the strongest predictor of skin cancer prevention behaviors $(\mathrm{p}<0.001)$.

Conclusion: The results showed that the structure of perceived self-efficacy and behavioral intention are the most effective factors on preventive behaviors of skin cancer. Therefore, it is recommended that in the field of development of educational interventions in the prevention of skin cancer, these structures should be considered more.

Key words: Skin cancer, Students, Extended parallel process model, Shahrekord

Funding: This study was funded by Islamic Azad University of Shahrekord.

Conflict of interest: None declared.

Ethical approval: The Ethics Committee of Islamic Azad University of Shahrekord approved the study (IR.IAU.SHK.REC.1400.015).

1- Assistant Prof., PhD in Health Education and Promotion, Dept. of Health, Faculty of Medical Sciences, Shahrekord Branch, Islamic Azad University, Shahrekord, Iran, ORCID: 0000-0002-5946-0955

(Corresponding Author) Tel: (038) 33361047, Fax:(038) 33361031, E-mail: zohrehkarimian68@gmail.com

2- Instructor, MSc in Midwifery, Dept. of Midwifery, Faculty of Medical Sciences, Shahrekord Branch, Islamic Azad University, Shahrekord, Iran, ORCID: 0000-0002-9261-3570

3- Instructor, MSc in Nursing, Dept. of Nursing, Faculty of Medical Sciences, Shahrekord Branch, Islamic Azad University, Shahrekord, Iran,ORCID: 0000-0002-8698-4367

4 Instructor, MSc in Nursing, Dept. of Nursing, Faculty of Medical Sciences, Shahrekord Branch, Islamic Azad University, Shahrekord, Iran, ORCID: 0000-0002-3285-9579 
How to cite this article: Karimiankakolaki Z, Rastak L, Khadibi M, Mohammadi P. Study of the Determinants of Protective Behavior Against Skin Cancer Based on the Extended Parallel Process Model in Medical Students of Shahrekord Branch of Azad University in 2021: A Descriptive Study. J Rafsanjan Univ Med Sci 2021; 20 (9): 1003-16. [Farsi] 